\title{
Filsafat Dakwah: Sebuah Upaya Keluar dari Kemelut
}

\author{
Enjang As \\ UIN Sunan Gunung Djati Bandung \\ E-mail: tunggulsunda@yahoo.com
}

\begin{abstract}
Preaching as part of the sacred duty of every Muslim is a human effort to do good and leave the evil and do mischief on the earth by strengthening potential Taqwa inspiration and inspiration fujur thus minimize potential human being in the way of the Lord. Therefore, the call can be regarded as the savior of mankind from the shackles of himself and his neighbor. On the basis of this propaganda is seen as a great work done for his fellow human beings, and are aware of work in order to humanize humans.
\end{abstract}

\section{Kata kunci:}

Dakwah, Masyarakat marhamah, Memanusiakan manusia

\section{A. Pendahuluan}

Dakwah dalam praktiknya merupakan kegiatan yang sudah sangat tua, karena eksistensinya "diyakini" telah hadir seiring dengan tugas dan fungsi yang diemban oleh manusia di belantara kehidupan mahakarya Pencipta alam semesta, yaitu sebagai khalifah fi al-ardh. Oleh karena itu, eksistensi dakwah merupakan sebuah realitas yang tidak dapat dipungkiri oleh siapa pun yang mengaku sebagai muslim. Selain karena memahaminya sebagai bagian dari kewajiban seorang muslim, juga disebabkan oleh adanya keyakinan bahwa dakwah merupakan bagian dari tugas suci (ibadah) yang mesti dijalankan oleh setiap pribadi muslim sesuai dengan kapasitasnya masing-masing. 
Namun sangat disayangkan, pemahaman "sebagian masyarakat" tentang dakwah hingga saat ini belum mengalami perubahan secara signifikan. Bahkan masih seringkali dikesani dan hanya disepadankan dengan kegiatan ceramah (khithabah) yang menjadi bagian dari tabligh, yaitu sebuah proses menyampaikan ajaran Islam secara verbalistik (ceramah) yang dilakukan oleh para mubaligh atau mubalighah dalam pengajian-pengajian di majlis taklim atau kegiatan ceramah keagamaan pada peringatan hari-hari besar Islam.

"Mungkin", disebabkan oleh ketidaktepatan dalam memahami dan memaknai dakwah inilah, umat Islam menjadi stagnan (jumud), umat Islam menjadi terbelakang, umat Islam menjadi penonton perubahan, bahkan hanya menjadi konsumen perubahan itu sendiri dan bukan menjadi pelaku perubahan peradaban dunia. Sekali lagi "mungkin", kondisi tersebut disebabkan oleh adanya kesalahan dalam memaknai dakwah.

Perkiraan tersebut cukup beralasan, karena dalam realitasnya pada "sebagian masyarakat" dakwah hanya dipandang sebagai proses penyampaian ajaran Islam secara verbalistik belaka, dan sasaran (objek) dakwah - seakan-akan -- dipandang sebagai entitas pasif. Sehingga setiap subjek dakwah (pelaku), bebas untuk menyampaikan apa pun sesuai dengan keyakinan, ideologi dan kebenaran perspektif pribadinya, serta kurang bahkan "tidak memberi" peluang kepada sasarannya (objek) untuk memanfaatkan potensi dirinya secara optimal. Bahkan pada beberapa di masyarakat, pelaku dakwah merasa sukses apabila sasaran dakwah (mad'u) telah dibuat terpingkal-pingkal sampai sakit kulit perut karena tertawa, atau atau merasa puas ketika melihat para mustaminya terkagum-kagum, bahkan menangis tersedu-sedu karena kepiwaian retorisnya dalam berpidato.

Sekalipun demikian, di satu sisi memang penting diakui bahwa kegiatan ceramah seperti itu bisa dikatakan telah sukses. Karena telah sukses menarik perhatian para audiennya (sasaran dakwah), telah sukses memalingkan perhatian mustaminya dari rutinitas kehidupan duniawi kepada kegiatan yang lebih berorientasi pada peningkatan kesadarannya sebagai manusia. Tetapi, tentu tidak cukup dan berhenti sampai disitu, karena dakwah bukan hanya sebagai proses membuat surga dalam telinga, atau menghadirkan neraka dalam imajinasi para 
pendengarnya. Lebih dari itu, bahwa dakwah merupakan upaya meningkatkan dan mewujudkan kesadaran puncak manusia, dan dalam rangka memanusiakan manusia agar dapat mencapai kebahagiaan hakiki dan bukan kebahagian semu yang bersifat sementara dan fatamorgana.

Berdasarkan asumsi di atas, maka di pandang perlu adanya kajian dakwah secara filosofis, sebagai upaya untuk menemukan dan memahami esensi dan substansi dakwah islamiyah. Langkah ini dibutuhkan agar tidak terjadi keslahpahaman dan kesalahmaknaan mengenai dakwah, atau paling tidak sebagai upaya untuk meminimalisasi kesalahpahaman dan kesalahmaknaan tentang dakwah islamiyah itu sendiri.

Selain itu, kajian filosofis ini pun merupakan upaya kritis kerja pemikiran atau penafsiran terhadap ayat-ayat dakwah yang terdapat dalam al-Qur'an yang menjadi kitab dakwah (Yusuf Musa, 1988). Kajian filosfis mengenai dakwah ini diwali oleh sebuah pertanyaan "apakah hakikat dakwah", pertanyaan ini akan sangat terkait dengan jawaban mengenai tujuan dakwah dan dampak yang diakibatkan jika dakwah tidak dilakukan.

Pertanyaan-pertanyaan tersebut di atas, semuanya berpangkal pada problem ontologis, yaitu terkait dengan apa yang hendak diketahui (Jujun S. Suriasumantri, 1985:363), atau esensi yang hendak dikaji, dan seringkali disebut sebagai pengkajian untuk mengetahui makna yang terdalam (beyond reality) atau hakikat kenyataan (realitas) dari sesuatu itu sendiri (Kattsoff, 1989: 76; Mutasir dan Misnal, 2000: 44-46). Dalam persoalan ini, pertanyaan yang banyak diketengahkan adalah terkait dengan "apa hakikat dakwah" dan "mengapa berdakwah". Inilah di antara persoalan ontologis dakwah (Anton Bakker, 1992: 15-16).

Upaya ini selain untuk mencermati dan memahami makna dakwah yang berkembang di tengah masyarakat, juga sebagai upaya untuk mengeliminasi kesalahmaknaan dan kesalahpahaman atas asumsi-asumsi filosofis tentang dakwah yang pada akhirnya akan menjadi bentuk pemikiran tunggal dan ekslusif, sehingga menolak tampilnya pemikiran-pemikiran baru mengenai dakwah yang "mungkin" lebih mendekati makna esensial dan substansial sebagaimana diharapkan oleh Sang Pencipta. 
Bertolak dari asumsi tersebut, kajian mengenai dakwah Islamiyah secara filosofis dipandang perlu, sebab upaya memungkinkan akan menemukan makna dakwah secara hakiki sebagaimana yang dimaksudkan dalam kitab dakwah. Setidaknya merupakan proses memahami makna dakwah dengan berbagai implikasinya. Karena itu pembahasannya pun, selain bersandar pada ayat al-Quran yang menjadi inspirasi awal untuk memahami dakwah, juga memanfaatkan tradisi berpikir filsafat (Amien, 1983:10). Setidaknya sebagai bagian dari upaya pencarian "ke-apa-an" dan "ke-mengapa-an" dakwah Islamiyah, serta bagian dari pemanfaatan kebebasan yang dimiliki oleh manusia secara bijaksana.

Kajian ini merupakan sebuah upaya kritis terhadap kesalahmaknaan dan kesalahpahaman tentang dakwah sebagaimana terdapat dalam risalah Tuhan dengan dakwah sebagai bentuk pemikiran yang mewujud sebagai proposisi filosofis yang dipandang sebagai bentuk pemikiran tunggal dan eksklusif, sehingga "menolak tampilnya" pemikiran-pemikiran baru (kreativitas intelektual) mengenai dakwah itu sendiri. Oleh sebab itu, sekalipun kajian ini berpijak pada tradisi kajian filsafat untuk menemukan "ke-apa-an" dan "ke-mengapa-an" dakwah Islamiyah, tetapi tidak bisa lepas dari risalah Tuhan sebagai bagian dari upaya memanfaaatkan kebebasan secara bijaksana.

\section{B. Potret Dakwah: Antara Cita dan Ralita}

Al-Qur'an merupakan salah satu di antara referensi yang banyak dibaca umat manusia, bahkan menjadi sumber pengetahuan dan inspirasi bagi kehidupan umat manusia dalam menapaki dinamika belantara kehidupan duniawi. Khususnya bagi umat Islam, al-Qur'an diyakini sebagai kitab suci terakhir yang diwahyukan Allah kepada Nabi Muhammad saw untuk dijadikan sebagai pedoman hidup (way of life) bagi umat manusia, dan dalam terminologi al-Quran disebut sebagai hudan li al-nâs.

Petunjuk bagi umat manusia pada umumnya dan sebagai pedoman bagi orang-orang yang bertakwa. Oleh sebab itu bagi orangorang yang meyakininya, al-Qur'an dipandang sebagai sumber hukum yang didalamnya dimuat berbagai aturan kehidupan yang tidak ada 
sesuatu pun yang dialpakan, karena al-Quran merupakan kitab hukum yang secara sempurna telah menjelaskan segala sesuatu yang dibutuhkan oleh manusia (QS. al-Nahl [16]: 89). Atas dasar itulah, maka petunjuk dan penjelasan mengenai dakwah dipahami terdapat didalamnya.

Dengan demikian, berbicara dan kajian tentang dakwah tidak dapat terlepas dari sumber hukum dakwah (al-Quran). Karena al-Qur'an merupakan kitab dakwah yang berfungsi sebagai penjelas, petunjuk dan menjadi tempat kembali yang utama (al-marju' al-'ala) dalam melakukan kajian dan pembahasan terkait dengan persoalan dakwah Islamiyah. Bahkan disebutkan Sayyid Qutb, bahwa al-Quran merupakan kitab dakwah (Al-Maududi, 1960:34), yang menjadi landasan untuk memahami tentang apa, mengapa dan bagaimana dakwah (Sayyid Qutb, Fiqih Dakwah, 1995:1).

Al-Qur'an dipandang sebagai motivator utama yang berfungsi sebagai penguat dan tempat berpijak, juga sebagai penjaga, penerang dan penjelas serta tempat kembali bagi para penyeru $\left(d a^{\prime} i\right)$ dalam mengambil rujukan dalam aktivitasnya. Di antara beberapa alasan yang menjadikan al-Quran di sebut sebagai kitab dakwah adalah karena alQur'an-lah yang memperkenalkan wacana dan menjelaskan segala sesuatu yang berkaitan dengan dakwah, termasuk diantaranya perintah mengenai wajibnya dakwah.

Al-Qur'an telah menjelaskan segala sesuatu yang berkenaan dengan dakwah, baik pada aspek esensi dan substansinya juga mengenai metodologinya. Lebih dari itu Syukriadi Sambas menjelaskan bahwa al-Quran, "selain sebagai kitab dakwah juga sebagai pesan dakwah Allah" (Syukriadi Sambas, 1998: 2). Karenanya, al-Qur'an menjadi salah satu refenrensi, bahkan menjadi rujukan utama dalam membicarakan dan memahami dakwah itu sendiri. Karena al-Quran telah memperkenalkan berbagai wacana dakwah, serta menjelaskan segala sesuatu yang berkenaan dengannya, termasuk perintah berdakwah bagi umat Islam.

Dalam al-Qur'an, terdapat banyak ayat yang memerintahkan berdakwah bagi umat Islam, sebagai upaya menyeru umat manusia agar melaksanakan kebaikan (al-ma'ruf) dan meninggalkan perbuatan buruk (al-munkar), agar manusia mau dan mampu berbuat baik kepada 
sesama, serta tidak berbuat kerusakan di (muka) bumi (Al-Qosos (28):77), proses penguatan potensi ilhâm taqwâ dan mengurangi potensi ilhâm fujûr, hingga manusia dapat mencapai "mukhbitîn". Selain itu, disebutkan juga bahwa di antara tujuan dakwah adalah menyeru umat manusia ke dar al-Islam (QS. Yunus [10]: 25), dan dalam ayat ayat lain disebut sebagai Jalan Tuhan (Al-Islam) (QS. Al-Nahl [16]:16).

Begitu pentingnya dakwah bagi kehidupan manusia, sehingga menurut al-Mawardi bahwa dakwah merupakan kewajiban dan urusan keagamaan (al-Qawaid al-Diniyah) (Imam al-Mawardi, 1393:258). Bahkan menurut pandangan Ibn Taimiyah, melaksanakan dakwah (ta'muruna bi al-ma'ruf wa tanhawna 'an al-munkar) merupakan kewajiban utama dan merupakan sebaik-baiknya perbuatan (Imam alMawardi, 1393:258). Bahkan atas dasar fungsinya itu sendiri sebagaimana tersirat dalam tujuannya -- maka kegiatan dakwah menjadi sesuatu yang dibutuhkan keberadaannya bagi kehidupan manusia itu sendiri. Sehingga kewajiban berdakwah, tidak menjadi pertentangan di antara para ulama, Bahkan dalam menetapkan hukum dakwah para ulama bersepakat, bahwa hukum melakukan dakwah adalah wajib.

Terlepas apakah termasuk dalam kategori wajib 'ain atau wajib kifayah. Perintah mengenai dakwah, banyak ditemukan dalam al-Qur'an, pada al-Sunnah serta Ijma' (ijm'a al-Umah). Juga terlepas apakah termasuk kategori wajib 'ain atau wajib kifayah, dakwah merupakan kewajiban bagi umat Islam yang menjalankan syari'at Islam sebagai agama risalah dan dakwah. Sehingga umat Islam berkewajiban untuk meneruskan risalah dengan dakwah sebagai upaya atau proses bagi kesempurnaan dan keselamatan hidup umat manusia.

Bertolak dari beberapa argumen normatif tersebut maka bagi seorang muslim, dakwah merupakan suatu kewajiban yang tidak bisa ditawar-tawar lagi. Kewajiban dakwah merupakan sesuatu yang bersifat conditio sine quanon, sesuatu tidak dapat dihindari oleh seorang muslim. Karena dakwah melekat erat bersamaan dengan pengakuan seseorang yang mengidentifikasi dirinya sebagai penganut ajaran Islam.

Pentinya dakwah sebagaimana dijelaskan di atas, terdapat beberapa argumen lain yang menyebabkan dakwah begitu penting bagi kehidupan umat manusia. Di antara argumennya adalah disandarkan 
pada rangkaian sejarah para nabi dan rasul yang menjadi subjek dakwah, dan melekat didalamnya tugas untuk menyelamatkan kehidupan umat manusia. Dalam beberapa kasus kisah para nabi dan rasul misalnya, kehadiran para nabi dan rasul diutus di tengah kondisi sosial manusia yang sedang mengalami degradasi moral atau di tengah kehidupan masyarakat yang tengah terjadi proses dehumanisasi. Nabi Musa dan Nabi Harun misalnya, keduanya diturunkan ketika tengah terjadi penghambaan manusia terhadap manusia lainnya.

Nabi Luth diturunkan ketika manusia sudah melupakan kodrat kemanusiaanya dengan melakukan perbuatan free sex dan homoseksual. Begitu juga ketika Nabi Muhammad saw. diutus di tengah masyarakat Mekah yang kondisi sosial budayanya, serta mental spiritualnya tidak jauh berbeda dengan kondisi masyarakat yang dihadapi oleh nabi sebelumnya. Terjadinya perbudakan, yang memandang sebagian manusia lainnya, tidak lebih baik dari hewan peliharaan yang dapat diperjualbelikan.

Kehadiran para nabi bukan hanya berkaitan dengan pengingkaran Dzat yang dipertuhankan (theosentris), melainkan erat pula kaitannya dengan permasalahan kemanusiaan (antroposentris), dan para nabi diutus untuk penyelamat umat manusia dari belenggu dirinya dan sesamanya. Kehadiran para nabi (Muhammad saw khususnya), sebagai upaya pembebasan manusia dari segala belenggu yang menghambat terealisasinya potensi fitrah manusia.

Dakwah yang dilakukan oleh para nabi dan rasul pada dasarnya sebagai upaya mempertahankan fitrah kemanusiaan, menuntun akal manusia dalam mencari dan menjalankan kebenaran, serta merealisasikan Islam sebagai rahmatan li al-alamin (Sambas, 1999: 11). Karena manusia membutuhkan orang lain atas kehidupannya, termasuk mendapatkan jawaban-jawaban atas persoalan yang dihadapinya.

Socrates (470-399 SM) misalnya, pernah menyatakan bahwa "dalam diri manusia terpendam jawaban mengenai berbagai persoalan dunia. Tetapi seringkali manusia itu tidak menyadari bahwa dalam dirinya terpendam jawaban-jawaban bagi persoalan yang dipertanyakannya. Karena ituperlu ada orang lain yang membantu orang itu mengemukakan jawaban-jawaban yang masih terpendam tersebut. Perlu adanya seseorang dalam membantu orang itu 
melahirkan ide yang ada dalam manusia tersebut" (Ahmad Tafsir, 2012: 11). Inilah di antara tugas para pelaku dakwah, memberikan jawaban atas berbagai persoalan yang dipertanyakan dan dihadapi oleh manusia berdasarkan pentunjuk Pencipta manusia yang dapat dipastikan sangat mengetahui tentang manusia dan berbagai persoalan yang dihadapi oleh manusia.

Inilah dakwah yang telah dilakukan oleh para nabi dan rasul, sehingga posisi dan fungsi dakwah begitu dibutuhkan bagi kehidupan umat manusia. Karena dakwah yang dilakukan merupakan upaya memberi jawaban atas pertanyaan dan persoalan yang dihadapi umat manusia. Bahkan merupakan sebuah proses penyelamatan umat manusia dari berbagai belenggu pemikiran, pemahaman, sikap dan perilaku yang merugikan, agar manusia agar mau dan mampu berbuat baik kepada sesama, tidak berbuat kerusakan di (muka) bumi (AlQoshosh (28):77).

Karenanya aktivitas dakwah dapat dipandang sebagai karya besar manusia yang dilakukan untuk sesamanya, dan merupakan kerja sadar dalam rangka memanusiakan manusia. Sehingga akan tetap dibutuhkan oleh umat manusia dalam rangka menumbuhkan dan mewujudkan kesadaran kemanusiaan manusia dalam wujud pribadi-pribadi yang memiliki kasih sayang terhadap sesama dan mewujudkan keshalehan sosial didalam tatanan masyarakat marhamah yang dilandasi oleh kebenaran tauhid, kesetaraan derajat, semangat persaudaraan, kesadaran akan arti penting kesejahteraan bersama, dan penegakkan keadilan di tengah-tengah kehidupan masyarakat. Selanjutnya agar dakwah dapat memanusiakan manusia, maka sangat penting memahami hakikat manusia itu sendiri. Jika tidak, maka kegiatan dakwah tidak menutup kemungkinan hanya akan menjadi ceremonial belaka.

\section{Membangun Perseptual dalam Memanusiakan Manusia}

Otak, dengan fungsinya yang rumit, dapat mengolah indrawi dalam banyak cara. Suatu kondisi syaraf yang disebut sinestesia, bahkan memungkinkan sebagian orang melihat musik, mendengarkan bentuk, atau mencicipi rasa sebuah nama. Orang-orang itu bukan gila kata 
Newberg dan Waldman, tetapi otak mereka mengolah informasi indrawi dengan cara yang unik (Newberg dan Waldman, 2013:110).

Otak yang menjadi gudang pemprosesan informasi indrawi melalui tubuh dan disalurkan lewat lusinan proses perspetual dan kognitif yang menganalisis, membedah, dan menyusun kembali informasi itu menjadi realitas internal. Kebanyak pemprosesan informasi ini berlangsung di lobus parietal, oksipital, dan temporal, terutama diperuntukkan bagi persepsi bawah sadar serta memori jangka panjang (B. Kolb dalam Andrew Newberg dan Mark Waldman, 2013: 288). Aktivitas saraflah yang mengubah cara kita memahami ralitas, dan tentunya ketika seseorang menerima apa saja sebagai sebuah kebenaran bisa jadi ia telah terjebak dalam ilusi yang mendatangkan kekeliruan.

Untuk tujuan ini, dalam rangka meminimalisasi kekeliruan dalam memanusiakan manusia langkah awal yang dapat ditempuh adalah memahami hakikat manusia itu sendiri. Tentunya tidak mudah untuk menjelaskan hakikat manusia ini, karena ilmu pengetahun modern pun tidak memiliki kapasitas untuk menjawab persoalan ini. Ilmu pengetahun modern hanya sampai pada pemahaman terbatas mengenai aspek-aspek telaah dan analisisnya. Akibatnya, dalam pemikiran semakin tidak memastikan tentang apakah benar-benar ada "perbedaan nyata" antara binatang dengan manusia (E. F. Schumacher, 1981: 23).

Oleh sebab itu, dalam rangka memanfaatkan kebebasan yang dimiliki oleh setiap manusia, juga sebagai upaya untuk menghindari kesalahan perseptual maka usaha untuk memahami hakikat manusia, menjadi tidak salah jika menggunakan penjelasan Pencipta seluruh langit dan bumi (fâthir al-samâwât wa al-ardl).

Penjelasan terbaik mengenai manusia yang datang dari Tuhan, tentunya akan kembali pada al-Quran yang menjadi kitab dakwah. Beberapa diantaranya disebutkan bahwa manusia memiliki unsur jasmani, dan jasmani ini merupakan salah satu esensi (hakikat) manusia. Aspek penting lainnya pada manusia adalah akal sebagai alat berpikir, sehingga manusia mau dan mampu berpikir, dan al-Quran menjelaskan bahwa akal ini merupakan bagian dari hakikat manusia. Selanjutnya, aspek penting pada manusia adalah ruhani yang disebut oleh Ahmad Tafsir sebagai al-Qolb yang menjadi tempat 
bersemayamnya iman, (Lebih lanjut lihat Thoyib I.M dan Sugiyanto, 2002:42), karena iman tidak bersemayam pada jasmani dan juga tidak bersemayam pada akal.

Pada beberapa ayat lain dijelaskan bahwa manusia memiliki kelebihan yang tidak dimiliki oleh makhluk lain dan kekurang. Di antara kelebihannya adalah (1) diberi daya berusaha dan usahanya dihargai (Qs. 53:79); (2) dijadikan sebagai khlaifah di bumi (Qs. 2:30; 6:122); (3) diberi alat indera dan akal (Qs. 16:78; 30:8). Sedangkan di antara kelemahan manusia adalah: (1) sombong dan mudah putus asa (Qs. 11:9; 17:67; 22:66; 100:6); (2) suka membantah (Qs. 16:4; 18:54); (3) suka tergesa-gesa (Qs. 21:37; 17:11; 75:20); (4) suka pelit (Qs. 17:100); (5) suka mengeluh (Qs. 70:20); (6) memiliki kecenderungan berbuat maksiat (Qs. 75:5); (7) mudah dipengaruhi hawa nafsu (Qs. 12:35); (8) cenderung melampaui batas (Qs. 12:35; 96:6-7); (8) suka mencelakan diri sendiri dan orang lain (Qs. 16:4; 18:54); (9) makhluk yang lemah (4:28). Selain itu manusia memiliki fitrah atau berpontensi untuk menjadi makhluk sosial (Qs. 49:13), berkecenderung untuk beragama (Qs. 5:3; 7:1720, dan memiliki rasa cinta terhadap wanita dan anakanak, kendaraan mewah, dan kekayaan lainnya (Qs. 3:14).

Dengan beberapa keterangan di atas, dapat dipahami bahwa manusia dengan berbagai kelebihan dan kekurangannya, juga dengan berbagai aspek yang dimilikinya (jasmani, akal, dan ruhani) ditemukan adanya iman yang bersemayam dalam al-qolb, yang dimiliki oleh setiap manusia sejak lahir (Lihat Mahdi Ghulsyani, 1986: 33, 149). Sementara peneliti Barat hanya menemukannya baru sebatas emosi (energi yang identik dengan nafsu), dan lebih maju dari itu peneliti Barat menyebutnya spirit. Kecuali penemuan terakhir yang dilakukan oleh Andrew Newberg dan Mark Waldmann yang kemudian disusun dalam bukunya yang berjudul "Born to Believe: God, Scinece, and the Origin of Ordinary and Extraordinary Beliefs".

Jika ini benar, maka dakwah yang dilakukan oleh setiap muslim, yaitu sebagai upaya untuk memanusiakan manusia bertolak dan berujung pada aspek keimanan manusia yang menjadi hakikat kemanusiaan manusia itu sendiri. Karena iman inilah yang akan menjadi world view-nya manusia, iman inilah yang akan mengkerangka tatapikir, tatasikap, dan tatalaku manusia. Oleh sebab jika manusia lemah atau 
bahkan tidak memiliki iman maka pada telinga mereka ada sumbatan (Qs. 41:44), hati mereka akan terkunci mati, karena itu mereka tidak akan mengerti (Qs. 63:3), akan menjadi sesat dalam hidupnya (Qs. 30:53), karena pengetahuannya hanya terbatas pada aspek kehidupan duniawi belaka (Qs. 53:29-30), karena hidupnya hanya mengikuti hawa nafsunya (Qs. 28:50), karena terkunci mati pendengaran dan hatinya (Qs. 45:23; 38:26).

Orang yang lemah dan tidak beriman hanya cinta dan benci buta, serta prasangka yang tidak beralasan disebabkan oleh kesalahan persepsi dirinya (penyakit hati) sebagaimana dijelaskan dalam Qs. 41:14; 29:38; 7:79; 16:107-108; 40:37, dan pada akhirnya akan menjadi takabur (Qs. 27:13-14) karena kebodohannya (Qs. 6:119; 22:8, dan 46:23), sehingga apa pun yang dilakukannya hanya didasarkan pada perkiraan yang tidak beralasan (Qs. 6:148; 10:39), karena mereka tidak berupaya memahami dengan hatinya (keimanannya).

\section{Penutup}

Dakwah sebagai bagian dari tugas suci setiap muslim merupakan upaya agar manusia melakukan kebaikan (al-ma'ruf) dan meninggalkan keburukan (al-munkar) serta melakukan kerusakan di muka bumi dengan cara menguatkan potensi ilhâm taqwâ dan meminimalisasi potensi ilhâm fujûr sehingga manusia berada pada jalan Tuhan (dar alIslam). Oleh sebab itu, dakwah dapat dikatakan sebagai proses penyelamat umat manusia dari belenggu dirinya dan sesamanya. Atas dasar inilah dakwah dipandang sebagai sebagai karya besar manusia yang dilakukan untuk sesamanya, dan merupakan kerja sadar dalam rangka memanusiakan manusia.

Selanjutnya karena dakwah diperuntukkan kepada manusia maka persoalan penting yang perlu diperhatikan dalam proses dakwah adalah bertolak pada penguatan keimanan manusia yang bersemayam pada alqalb sebagai quwwah qudsiyah untuk mencapai realitas ekstra mental yang tidak terbatas pada objek-objek konkrit dan menjadi dasar lahirnya yang sekaligus menjadi bingkai pandangan dunia (world view) setiap manusia yang kemudian menjadi energi penggerak juga menjadi kontrol tatapikir, tatasikap dan tatalaku manusia.[] 


\section{DAFTAR PUSTAKA}

Al-Maududi, Abu al-A'la. 1960. al-Mabadi al-Asasiyyah li Fahm al-Qur'an, Lahore: Dar al-Arubah li al-Da'wah al-Islamiyah

Al-Mawardi, Imam. 1393 H. Al-Ahkam al-Sulthaniyah, Mesir: Syirkah wa Matba'ah Musthafa al-Baby

Al-Quran Karim

Amien, Muhammad. 1983. Epistemologi Islam: Pengantar Filsafat Pengetahuan Islam, Jakarta: Universitas Indonesia

Bagus, Loren. 1991. Metafisika, Jakarta: Gramedia

Bakker, Anton. 1992. Ontologi, Metafisika Umum, Yogyakarta: Kanisius

Devos, 1987. Inleiding tot de Ethiek, alih bahasa Soejono Soemargono, Yogyakarta: Tiara Wacana

Ghulsyani, Mahdi. 1986. Filsafat-Sains Menurut Al-Quran, terj. Agus Effendi, Bandung: Mizan

Ibn Taimiyah, Syaikh al-Islam. 1396 H. al-Amr bi al-Ma'ruf wa al-Nahy 'an al-Munkar, Beirut: Dar al-Kitab al-Jadid

Kattsoff, Louis O. 1989. Pengantar Filsafat, terj. Soejono Soemargono, Yogyakarta: Tiara Wacana

Muntasir, Rizal dan Misnal, Munir. 2000. Filsafat Ilmu, Yogyakarta: Pustaka Pelajar

Musa, Abu. 1988. al-Qur'an wa al-Falsafah, terj. Ahmad Daudy, Jakarta: Bulan Bintang

Musa, Yusuf . 1988. Al-Quran dan Filsafat, terj. Ahmad Daudy, Jakarta: Bulan Bintang

Muthahari, Murthada. 1994. Fundamental of Islamic, alih bahasa Agus Effendi, Bandung: Mizan

Newberg, Andrew dan Waldman, Mark. 2013. Born to Believe: God, Scinece, and the Origin of Ordinary and Extraordinary Beliefs, terj. Eva Y. Nukman, Bandung: PT. Mizan Pustaka

Qutb, Sayyid. 1995. Fiqih Dakwah, Jakarta: Pustaka Amini

Sambas, Syukriadi. 1998. Sembilan Pasal Pokok-pokok Filsafat Dakwah, Bandung: KP Hadid 
Schumacher, E. F. 1981. Keluar dari Kemelut: Sebuah Peta Pemikiran Baru, Jakarta: LP3ES

Suriasumantri, Yuyun. 1982. Ilmu dalam Perspektif, Jakarta: Yayasan Obor Indonesia dan Leknas LIPI

Tafsir, Ahmad. 2012. Filsafat Pendidikan Islami, Bandung: PT. Remaja Rosdakarya

Thoyib I.M dan Sugiyanto, 2002. Islam dan Pranata Sosial Kemasyarakatan, Bandung: Remaja Rosdakarya

Van Laer, Henry. 1995. Filsafat Sains: Ilmu Pengetahuan Secara Umum, Alih Bahasa Yudiana W. Asmin dan Torang Rambe, Yogyakarta: LPMI 